\title{
SARS-CoV-2 Detection Rates from Surface Samples Do Not Implicate Public Surfaces as Relevant Sources for Transmission
}

\author{
Günter Kampf ${ }^{1, *}$, Stephanie Pfaender ${ }^{2}$, Emanuel Goldman ${ }^{3}$ (D) and Eike Steinmann ${ }^{2}$ \\ 1 Institute for Hygiene and Environmental Medicine, University Medicine Greifswald, \\ 17475 Greifswald, Germany \\ 2 Department of Molecular and Medical Virology, Ruhr University Bochum, 44801 Bochum, Germany; \\ stephanie.pfaender@ruhr-uni-bochum.de (S.P.); Eike.Steinmann@ruhr-uni-bochum.de (E.S.) \\ 3 Department of Microbiology, New Jersey Medical School-Rutgers University, Newark, NJ 07103, USA; \\ egoldman@njms.rutgers.edu \\ * Correspondence: guenter.kampf@uni-greifswald.de
}

Citation: Kampf, G.; Pfaender, S.; Goldman, E.; Steinmann, E. SARS-CoV-2 Detection Rates from Surface Samples Do Not Implicate Public Surfaces as Relevant Sources for Transmission. Hygiene 2021, 1 , 24-40. https://doi.org/10.3390/ hygiene1010003

Received: 4 April 2021

Accepted: 18 May 2021

Published: 21 May 2021

Publisher's Note: MDPI stays neutral with regard to jurisdictional claims in published maps and institutional affiliations.

Copyright: (c) 2021 by the authors. Licensee MDPI, Basel, Switzerland. This article is an open access article distributed under the terms and conditions of the Creative Commons Attribution (CC BY) license (https:// creativecommons.org/licenses/by/ $4.0 /)$.

\begin{abstract}
Contaminated surfaces have been discussed as a possible source of severe acute respiratory syndrome coronavirus-2 (SARS-CoV-2). Under experimental conditions, SARS-CoV-2 can remain infectious on surfaces for several days. However, the frequency of SARS-CoV-2 detection on surfaces in healthcare settings and the public is currently not known. A systematic literature review was performed. On surfaces around COVID-19 cases in healthcare settings (42 studies), the SARS-CoV2 RNA detection rates mostly were between $0 \%$ and $27 \%$ (Ct values mostly $>30$ ). Detection of infectious SARS-CoV-2 was only successful in one of seven studies in $9.2 \%$ of 76 samples. Most of the positive samples were obtained next to a patient with frequent sputum spitting during sampling. Eight studies were found with data from public surfaces and RNA detection rates between $0 \%$ and $22.1 \%$ (Ct values mostly > 30). Detection of infectious virus was not attempted. Similar results were found in samples from surfaces around confirmed COVID-19 cases in non-healthcare settings (7 studies) and from personal protective equipment (10 studies). Therefore, it seems plausible to assume that inanimate surfaces are not a relevant source for transmission of SARS-CoV-2. In public settings, the associated risks of regular surface disinfection probably outweigh the expectable health benefits.
\end{abstract}

Keywords: SARS-CoV-2; surface; contamination; RNA; infectious virus

\section{Introduction}

The global spread of SARS-CoV-2 in 2020 has resulted in a variety of strategies for transmission control. Early laboratory data obtained after an artificial contamination of carrier surfaces with a high viral load suggested that coronaviruses in general may remain infectious on inanimate surfaces at room temperature for up to 9 days [1] and in the dark and in the presence of bovine serum albumin for even up to 28 days [2]. Similar results, though with much shorter stability times, were obtained with SARS-CoV-2 under laboratory settings [3]. The relevance of the rather long persistence on surfaces remains controversial because viruses from respiratory secretions are embedded in mucus and saliva, which probably contain specific antibodies against the virus, high numbers of leukocytes, and intrinsic antiviral activity because of their polyanionic charge which binds to viruses as well as bacteria and fungi, which may influence the environment around the virus [4]. The applicability of the findings to real life has also been questioned because in the studies, a high load of infectious virus was applied to a small surface area, which is much higher than those in droplets in real-life situations. As a result, the amount of virus actually deposited on surfaces could be several orders of magnitude smaller [5]. Nevertheless, these findings obtained under laboratory conditions raised the concern that viral shedders in the public may contaminate frequent touch surfaces, finally resulting in 
viral transmission via uncontrolled hand-face-contacts. As a result, many public surfaces were subjected to disinfection, e.g., in shops, museums, restaurants, public transportation, or sports facilities.

Recent data suggest that infectious SARS-CoV-2 is rarely found on surfaces around confirmed COVID-19 cases in healthcare settings despite variable detection rates of viral RNA [6,7]. Laboratory data with SARS-CoV-2 show that Ct (cycle threshold) values of 29.3 (steel surface) or 29.5 (plastic surface) correlate with detection of culturable virus, whereas Ct values of 32.5 (steel surface) or 32.7 (plastic surface) correlate with the detection of non-culturable virus [6]. It was implicated that a $\mathrm{Ct}$ value $>30$ obtained from a surface sample has probably no epidemiological relevance [6]. In contrast, dried inocula with $\mathrm{Ct}$ values $<30$ (corresponding to an E gene copy number of $\geq 10^{5}$ per $\mathrm{mL}$ ) yielded SARS-CoV-2 that could be cultured [6]. A simple binary approach to the interpretation of PCR results obtained from surface samples and not validated against viral culture will probably result in unnecessary, regular disinfection of surfaces [8]. The frequency of SARS-CoV-2 detection by PCR on surfaces in healthcare settings and the public is currently not known. In addition, the corresponding $\mathrm{Ct}$ values have not been comprehensively evaluated. The aim of this review is to summarize published data on this aspect.

\section{Materials and Methods}

A Medline search was done on 13 October 2020 and updated on 1 April 2021 using the following terms: SARS-CoV-2 surface contamination (261 hits) and SARS-CoV-2 PPE contamination (79 hits). All studies were screened for original data of surface contamination with SARS-CoV-2 (RNA, including Ct values and infectious virus). Data were extracted from studies that described the presence of SARS-CoV-2, both RNA and infectious virus, on surfaces. Reviews were not included but were screened for any information relevant to the scope of this review.

\section{Results}

\subsection{Areas Surrounding Confirmed COVID-19 Cases in Healthcare Settings}

Overall, 42 studies were found with data on the presence of SARS-CoV-2 RNA in the areas surrounding confirmed COVID-19 patients in healthcare settings. In 27 of the studies, no specific information was available when the last cleaning or disinfection was done prior to sampling $[6,7,9-33]$. In two studies, sampling was performed prior to cleaning with 1000 ppm sodium hypochlorite [34,35], and in five studies it was done before the next scheduled surface cleaning [36-40]. Other investigators performed surface sampling at least four hours after the last cleaning procedure [41,42], within four to seven hours after the first daily cleaning [43], seven hours after cleaning and disinfection [44], at least eight hours after any cleaning procedure [45], before and after decontamination [46,47], or after terminal disinfection [48].

For none of the confirmed COVID-19 patients was it attempted to detect infectious SARS-CoV-2 from respiratory tract samples at the time of diagnosis or at the time of surface sampling. In 14 studies, there was evidence that COVID-19 patients were SARS-CoV-2RNA-positive. Five studies reported the corresponding $\mathrm{Ct}$ values, which were between 13.7 and 39.0. The detection rate of SARS-CoV-2 RNA on surfaces was mostly between $0 \%$ and $27 \%$ of all samples. Most of the corresponding $\mathrm{Ct}$ values were $>30$. Detection of infectious virus was attempted in 7 of the 42 studies. Only one study provided evidence for infectious SARS-CoV-2 in $10.5 \%$ of 76 samples. Seven of the eight positive samples were obtained in the area surrounding one patient with persistent cough and frequent sputum spitting during sampling. All samples from the other six studies were culture negative (Table 1). 


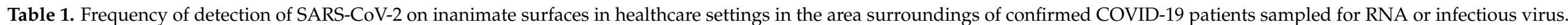

\begin{tabular}{|c|c|c|c|c|c|c|c|}
\hline Setting (Country) & Types of Sampled Surfaces (n) & $\begin{array}{l}\text { Evidence for Infectious } \\
\text { Virus in Samples from } \\
\text { Cases (Ct Values of } \\
\text { Clinical Samples) }\end{array}$ & $\begin{array}{c}\text { Targets on } \\
\text { SARS-CoV-2 Genome }\end{array}$ & $\begin{array}{l}\text { Sample Considered } \\
\text { Positive with Ct Value } \\
\text { of }\end{array}$ & $\begin{array}{l}\text { Proportion } \\
\text { of Viral RNA } \\
\text { Detection }\end{array}$ & Ct Values & Reference \\
\hline $\begin{array}{l}\text { Hospital with COVID-19 } \\
\text { patients (USA) }\end{array}$ & $\begin{array}{l}\text { Surfaces in the patient } \\
\text { surrounding (734) }\end{array}$ & No * (no Ct values) & $\mathrm{E}$ and $\mathrm{N}$ genes & $<40$ & $13.1 \%$ & $\begin{array}{l}\text { Not specified; } 10^{2}-10^{5} \text { viral } \\
\text { copies detected in positive } \\
\text { samples }\end{array}$ & [9] \\
\hline $\begin{array}{l}\text { Different wards in grade III } \\
\text { hospital (China) }\end{array}$ & Surfaces on different wards (626) & No & ORF1ab and $\mathrm{N}$ genes & $<40$ & $13.6 \%$ & Not described & [10] \\
\hline $\begin{array}{l}\text { Dedicated general ward for } \\
\text { COVID-19 cases (Singapore) }\end{array}$ & $\begin{array}{c}\text { Various high-touch surfaces in } \\
\text { the patient surroundings and } \\
\text { toilet area (445) }\end{array}$ & No * (no Ct values) & $\begin{array}{l}\text { E and ORF1b-nsp14 } \\
\text { genes }\end{array}$ & Not described & $2.2 \%$ & Not described & [34] \\
\hline $\begin{array}{l}\text { Various healthcare settings } \\
\text { (Brazil) }\end{array}$ & Various surfaces (403) & No & $\mathrm{N} 1$ and $\mathrm{N} 2$ genes & $<40$ & $5.0 \%$ & $\begin{array}{c}23.3-37.7(\mathrm{~N} 1) \text { and } 22.2-39.4 \\
(\mathrm{~N} 2)\end{array}$ & [11] \\
\hline $\begin{array}{l}\text { COVID-19 isolation rooms } \\
\text { (China) }\end{array}$ & Surfaces in patient rooms (377) & No & RdRp gene & Not described & $5.0 \%$ & $\begin{array}{c}1.1 \times 10^{2}-9.4 \times 10^{4} \mathrm{RNA} \\
\text { copies per ml }\end{array}$ & [35] \\
\hline $\begin{array}{l}\text { Treatment rooms for COVID-19 } \\
\text { patients (England) }\end{array}$ & $\begin{array}{l}\text { High contact surfaces in patient } \\
\text { rooms (336) }\end{array}$ & $\begin{array}{c}\mathrm{No}^{*} \text { (17.7 and } 21.4 ; 2 \text { of } \\
44 \mathrm{Ct} \text { values) }\end{array}$ & $\begin{array}{l}\text { RdRp, N, ORF1ab, } \\
\text { and E genes }\end{array}$ & $<40$ & $8.9 \% * *$ & $28.8-39.1$ & [12] \\
\hline $\begin{array}{l}\text { Rooms of COVID-19 patients in } \\
\text { four hospitals (Republic of } \\
\text { Korea) }\end{array}$ & Various surfaces (330) & 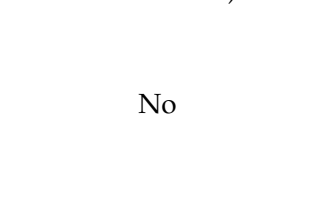 & RdRp and E genes & $<35$ & $27.0 \%$ & $\begin{array}{c}25-39 \text {; values }<30 \text { only on } \\
\text { bedside rail ( } 2 \text { samples), } \\
\text { sink internal bowel (1 } \\
\text { sample), floor ( } 1 \text { sample), } \\
\text { and bathroom door handle } \\
\text { (1 sample) }\end{array}$ & [36] \\
\hline $\begin{array}{l}\text { Four hospitals with COVID-19 } \\
\text { patients (China) }\end{array}$ & Various surfaces (318) & No & ORFab and $\mathrm{N}$ genes & $<40$ & $3.1 \%$ & 3-8 RNA copies per $\mathrm{cm}^{2}$ & [13] \\
\hline $\begin{array}{l}\text { Surfaces in } 27 \text { hospital rooms of } \\
\text { COVID-19 patients (Singapore) }\end{array}$ & Various surfaces (245) & No * (20.4-35.7) & ORF1ab and E genes & $\leq 45$ & $22.9 \%$ & Not described & [14] \\
\hline $\begin{array}{l}\text { Designated COVID-19 hospital } \\
\text { (China) }\end{array}$ & $\begin{array}{l}\text { Various surfaces in isolation } \\
\text { wards and ICUs (244) }\end{array}$ & No & ORF1ab gene & Not specified & $4.1 \%$ & Not specified & [37] \\
\hline $\begin{array}{l}\text { Teaching hospital with } \\
\text { COVID-19 patients (UK) }\end{array}$ & $\begin{array}{l}\text { Various surfaces in different } \\
\text { parts of the hospital (218) }\end{array}$ & No & E gene & $<40.4$ & $10.6 \% * *$ & $\begin{array}{l}\text { Not specified; } 10^{1}-10^{4} \\
\text { genome copies detected in } \\
\text { positive samples }\end{array}$ & [6] \\
\hline COVID-19 hospital (China) & $\begin{array}{l}\text { Surfaces frequently touched by } \\
\text { patients or healthcare workers } \\
\text { (200) }\end{array}$ & No & RdRp, N, and E genes & $\leq 43$ & $19.0 \%$ & Not described & [15] \\
\hline COVID-19 ICU (Singapore) & $\begin{array}{l}\text { Various surfaces in } 20 \text { patient } \\
\text { rooms }(200)\end{array}$ & $\mathrm{No}^{*}(23.1-39.0)$ & ORF1ab and E genes & $<45$ & $14.0 \%$ & Not described & [16] \\
\hline Emergency department (France) & $\begin{array}{l}\text { Different surfaces from the } \\
\text { patient care area (102) and the } \\
\text { non-patient care area (74) }\end{array}$ & No & ORF1ab and E genes & Not described & $5.1 \% * * *$ & $35.7-39.7$ & [46] \\
\hline $\begin{array}{l}\text { ICU with COVID-19 patients } \\
\text { (Switzerland) }\end{array}$ & $\begin{array}{l}\text { Different surfaces in patient } \\
\text { rooms after terminal } \\
\text { disinfection (176) }\end{array}$ & No & Not described & Not described & $0 \%$ & - & [48] \\
\hline
\end{tabular}


Table 1. Cont.

\begin{tabular}{|c|c|c|c|c|c|c|c|}
\hline Setting (Country) & $\begin{array}{c}\text { Types of Sampled Surfaces } \\
\text { (n) }\end{array}$ & $\begin{array}{c}\text { Evidence for } \\
\text { Infectious Virus in } \\
\text { Samples from Cases } \\
\text { (Ct Values of } \\
\text { Clinical Samples) }\end{array}$ & $\begin{array}{l}\text { Targets on } \\
\text { SARS-CoV-2 } \\
\text { Genome }\end{array}$ & $\begin{array}{l}\text { Sample Considered } \\
\text { Positive with Ct } \\
\text { Value of }\end{array}$ & $\begin{array}{c}\text { Proportion } \\
\text { of Viral } \\
\text { RNA } \\
\text { Detection }\end{array}$ & Ct Values & Reference \\
\hline $\begin{array}{l}\text { COVID-19 treatment centre } \\
\text { for patients after } \\
\text { tracheostomy (China) }\end{array}$ & Various surfaces (152) & No & $\begin{array}{l}\text { ORF1ab and NP } \\
\text { genes }\end{array}$ & $<40$ & $1.3 \%$ & $36.8-37.5$ & [17] \\
\hline $\begin{array}{l}\text { Intensive care unit and } \\
\text { ordinary ward with } \\
\text { COVID-19 cases (Taiwan) }\end{array}$ & $\begin{array}{c}\text { Samples from } 16 \text { different } \\
\text { surfaces (144) }\end{array}$ & No & $\begin{array}{l}\text { RdRp, } N \text {, and } \mathrm{E} \\
\text { genes }\end{array}$ & $<45$ & $1.4 \%$ & $30.4,31.8$ & [38] \\
\hline $\begin{array}{l}\text { Designated COVID-19 } \\
\text { hospital (China) }\end{array}$ & $\begin{array}{l}\text { Various surfaces on isolation } \\
\text { ward (144) }\end{array}$ & No & ORF1 and $N$ genes & $\begin{array}{l}<40 \\
<45\end{array}$ & $\begin{array}{c}0.7 \% \\
2.8 \% \\
17.0 \%(7.5 \% \\
* * * *)\end{array}$ & $\begin{array}{c}38.6 \\
41.0-44.8\end{array}$ & [18] \\
\hline $\begin{array}{c}\text { Contaminated, } \\
\text { semi-contaminated, } \\
\text { and clean areas of an ICU } \\
\text { with COVID-19 patients } \\
\text { (China) }\end{array}$ & $\begin{array}{c}\text { Floor (53) } \\
\text { Doorknob (34) } \\
\text { Air outlet filter (18) } \\
\text { Sickbed handrail (14) } \\
\text { Computer mouse (8) } \\
\text { Trash can (5) }\end{array}$ & No & ORF1ab and $\mathrm{N}$ genes & Not described & $\begin{array}{c}0 \% \\
44.4 \% \\
(22.2 \% * * * *) \\
43 \%(29 \% \\
* * * *) \\
75 \%(25 \% \\
* * * *) \\
60 \%(60 \% \\
* * * *)\end{array}$ & $\begin{array}{c}\text { No Ct values described; } \\
\text { average RNA } \\
\text { concentration between } \\
2.9 \times 10^{3} \text { and } 1.5 \times 10^{5}\end{array}$ & [19] \\
\hline $\begin{array}{l}\text { ICU with COVID-19 patients } \\
\text { (France) }\end{array}$ & $\begin{array}{l}\text { Various frequently touched } \\
\text { surfaces (117) }\end{array}$ & No* (no Ct values) & E gene & Not described & $24.8 \%$ & 29.0-39.0 (median: 36) & [45] \\
\hline $\begin{array}{l}\text { COVID-19 isolation ward } \\
\text { (China) }\end{array}$ & $\begin{array}{l}\text { Surfaces in patient rooms } \\
\text { and the toilet area (112) }\end{array}$ & No * (no Ct values) & ORF1ab and N genes & Not described & $39.3 \%$ & Not described & {$[43]$} \\
\hline & & & $\begin{array}{l}\text { RdRp, } \mathrm{N} \text {, and } \mathrm{E} \\
\text { genes }\end{array}$ & & $3.8 \%$ & & \\
\hline \multirow[t]{2}{*}{$\begin{array}{l}\text { Intensive care unit, isolation } \\
\text { ward, and general ward } \\
\text { (Republic of Korea) }\end{array}$} & $\begin{array}{l}\text { Surfaces in patient rooms, } \\
\text { the ante room, the floor of an } \\
\text { adjacent common corridor, } \\
\text { and the nursing station (105) }\end{array}$ & No & $\begin{array}{l}\text { Only two of the } \\
\text { genes positive }\end{array}$ & Not described & $4.8 \%$ & Not described & [20] \\
\hline & & & $\begin{array}{l}\text { Only one of the genes } \\
\text { positive }\end{array}$ & & $3.8 \%$ & & \\
\hline $\begin{array}{c}\text { COVID-19 isolation ward } \\
\text { (China) }\end{array}$ & Various surfaces (84) & No & ORF1ab and $\mathrm{N}$ genes & $<37$ & $7.1 \%$ & Not described & [21] \\
\hline
\end{tabular}


Table 1. Cont.

\begin{tabular}{|c|c|c|c|c|c|c|c|}
\hline Setting (Country) & $\begin{array}{c}\text { Types of Sampled Surfaces } \\
\text { (n) }\end{array}$ & $\begin{array}{c}\text { Evidence for } \\
\text { Infectious Virus in } \\
\text { Samples from Cases } \\
\text { (Ct Values of } \\
\text { Clinical Samples) }\end{array}$ & $\begin{array}{c}\text { Targets on } \\
\text { SARS-CoV-2 } \\
\text { Genome }\end{array}$ & $\begin{array}{l}\text { Sample Considered } \\
\text { Positive with Ct } \\
\text { Value of }\end{array}$ & $\begin{array}{l}\text { Proportion } \\
\text { of Viral } \\
\text { RNA } \\
\text { Detection }\end{array}$ & Ct Values & Reference \\
\hline $\begin{array}{l}\text { Isolation rooms for } \\
\text { COVID-19 patients (Ireland) }\end{array}$ & $\begin{array}{l}\text { Various surfaces in isolation } \\
\text { rooms and the nurses' } \\
\text { station }(81)\end{array}$ & No & $\mathrm{N} 2$ and $\mathrm{E}$ genes & Not described & $16 \%$ & Not described & [41] \\
\hline $\begin{array}{l}\text { Hospital, rehabilitation } \\
\text { centre, and apartment } \\
\text { building complex with } \\
\text { COVID-19 patients } \\
\text { (Republic of Korea) }\end{array}$ & $\begin{array}{l}\text { Surfaces frequently touched } \\
\text { by the patients }(80)\end{array}$ & No & $\begin{array}{l}\text { RdRp gene } \\
\text { E gene }\end{array}$ & $<35$ & $2.5 \%$ & $\begin{array}{l}27.8,32.9 \\
31.5,34.8\end{array}$ & [22] \\
\hline $\begin{array}{c}\text { Dedicated SARS-CoV-2 } \\
\text { outbreak centre (Singapore) }\end{array}$ & $\begin{array}{c}\text { Patient rooms A and B: } \\
\text { various surfaces after routine } \\
\text { cleaning (52) } \\
\text { Patient room C: various } \\
\text { surfaces before routine } \\
\text { cleaning }(28)\end{array}$ & $\mathrm{No}^{*}(23.2-35.3)$ & RdRp and E genes & $\leq 45$ & $\begin{array}{c}0 \% \\
60.7 \%\end{array}$ & $\begin{array}{c}- \\
30.6-38.2(\text { mostly }>34)\end{array}$ & [47] \\
\hline $\begin{array}{l}\text { Severe COVID-19 cases in } \\
\text { isolation rooms (Republic of } \\
\text { Korea) }\end{array}$ & $\begin{array}{l}\text { Surroundings of three } \\
\text { patients }(76)\end{array}$ & $\mathrm{No}^{*}(15.3-26.2)$ & RdRp and E genes & $\leq 35$ & $19.7 \% * * * * *$ & 28.9-33.0 (mostly > 30) & [7] \\
\hline COVID-19 ICU (Singapore) & $\begin{array}{l}\text { Various surfaces in common } \\
\text { areas and staff pantry (75) }\end{array}$ & $\mathrm{No}^{*}(23.1-39.0)$ & ORF1ab and E genes & $<45$ & $10.7 \%$ ** & $36.2-38.1$ & [16] \\
\hline COVID-19 ICU (Spain) & $\begin{array}{c}\text { Various surfaces in } 3 \text { risk } \\
\text { areas (72) }\end{array}$ & No & ORF1 $\mathrm{ab}$ and $\mathrm{N}$ genes & Not described & $0 \%$ & - & [23] \\
\hline $\begin{array}{l}\text { COVID-19 isolation unit } \\
\text { (Israel) }\end{array}$ & Various surfaces (55) & No * (no Ct values) & E gene & $<45$ & $52.7 \%$ ** & $30.0-39.8$ & [24] \\
\hline $\begin{array}{l}\text { COVID-19 isolation ward } \\
\text { (China) }\end{array}$ & Various surfaces (50) & No & E gene & $\leq 40$ & $8.0 \%$ ** & $29.4-33.6$ & [25] \\
\hline $\begin{array}{l}\text { COVID-19 isolation ward } \\
\text { (Iran) }\end{array}$ & Various surfaces (50) & No & ORF1 $\mathrm{ab}$ and $\mathrm{N}$ genes & $\leq 40$ & $18.0 \% * *$ & $30.9-38.2$ & [26] \\
\hline $\begin{array}{l}\text { COVID-19 reference } \\
\text { hospitals (Italy) }\end{array}$ & Various surfaces (49) & No & $\begin{array}{l}\text { RdRp, } \mathrm{N} \text {, and } \mathrm{E} \\
\text { genes }\end{array}$ & $<40$ & $6.1 \% * * *$ & Not described & [27] \\
\hline $\begin{array}{l}\text { Quarantine room of three } \\
\text { COVID-19 patients (China) }\end{array}$ & Various surfaces (41) & No * (20-39) & ORF1ab gene & $<37$ & $34.1 \%$ & 26-38 (median: 35) & [28] \\
\hline
\end{tabular}


Table 1. Cont.

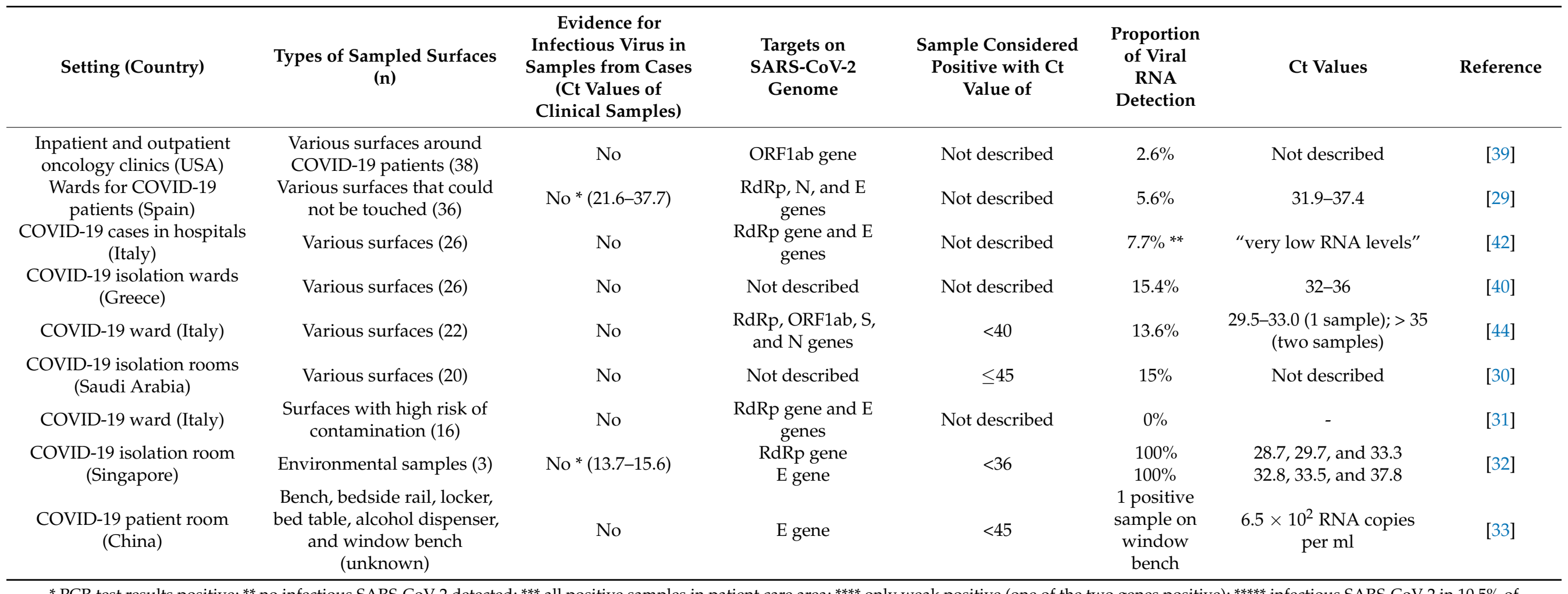

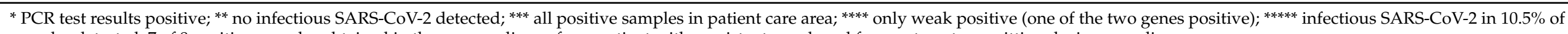
samples detected, 7 of 8 positive samples obtained in the surroundings of one patient with persistent cough and frequent sputum spitting during sampling. 


\subsection{Areas Surrounding Confirmed COVID-19 Cases in Non-Healthcare Settings}

A total of seven studies provide data on SARS-CoV-2 detection on surfaces around confirmed COVID-19 cases in non-healthcare settings. The epidemiological situation during the study period was described in three of the seven studies. It was during an ongoing COVID-19 outbreak investigation on a ferry boat [40], during a COVID-19 outbreak on a cruise ship [49], during a COVID-19 outbreak in a nursing home [40], and during a local COVID-19 outbreak [50]. No specific information regarding the local or national epidemiological situation during the study period was found in four of the studies [51-54].

In three studies, samples were taken before any cleaning or disinfection procedure was carried out $[40,49,54]$. In one study, $50 \%$ of the 428 samples were taken before the cleaning and disinfection, and the other half was taken after the disinfection procedure [51]. No specific information regarding any prior treatment of surfaces was found in three studies $[50,52,53]$. The public availability of hand sanitizers was not described in any of the studies [40,49-54].

For none of the confirmed COVID-19 patients was it attempted to detect infectious SARS-CoV-2 from respiratory tract samples at the time of diagnosis or at the time of surface sampling. Six studies confirm the presence of SARS-CoV-2 RNA in respiratory samples, with $\mathrm{Ct}$ values in one study between 25.7 and 33.1. The detection rate of SARS-CoV-2 RNA on surfaces was mostly between $0 \%$ and $20 \%$ of all samples with corresponding $\mathrm{Ct}$ values mostly $>30$. In two of the four studies, detection of infectious SARS-CoV-2 was attempted. All samples, however, were culture negative (Table 2).

\subsection{Public Surfaces}

Eight studies were found with data on the contamination of public surfaces with SARS-CoV-2. The epidemiological situation during the study period was described in four studies. In Brazil, the study took place in one of the regions with the highest number of notified COVID-19 cases [11]. In the U.S., sampling was done during a regional COVID-19 outbreak [55]. In Iran, sampling was performed during the early stage of a local outbreak [56]. In Italy, surfaces were samples 2-3 months after the national epidemic peak [27]. No information was found in the other studies [30,57-59].

The RNA detection rates were low, at $0 \%$ to $22.1 \%$; the corresponding $\mathrm{Ct}$ values were mostly $>30$. There were no attempts to detect infectious virus (Table 3). In seven of eight studies, it was not described if any of the sampled surfaces was cleaned or disinfected before the sampling took place $[11,27,30,55-57,59]$. In one study, however, samples were taken four hours after surface disinfection with $1000 \mathrm{ppm}$ sodium hypochlorite [58]. In addition, in one study, it was described that surface disinfection was initiated in a public building after the positive results were communicated, suggesting that surface disinfection was not done routinely [11]. The public availability of hand sanitizers was not described in any of the studies $[11,27,30,55-59]$.

\subsection{Personal Protective Equipment}

Ten studies were found with data on the contamination of surfaces of PPE. In none of the studies was it confirmed that the COVID-19 patients harboured infectious SARS-CoV-2. In four studies, there was evidence that the COVID-19 patients were SARS-CoV-2-RNApositive with corresponding $\mathrm{Ct}$ values between 13.7 and 37.9. SARS-CoV-2 RNA was detected on $0 \%$ to $33.3 \%$ of all samples with either a low RNA concentration or high corresponding $\mathrm{Ct}$ values $>38$. None of the studies attempted to detect infectious SARSCoV-2 (Table 4). 


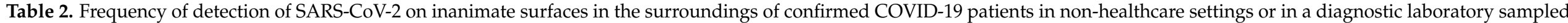
for RNA or infectious virus.

\begin{tabular}{|c|c|c|c|c|c|c|c|}
\hline Setting (Country) & Types of Sampled Surfaces (n) & $\begin{array}{l}\text { Evidence for Infectious } \\
\text { Virus in Samples from } \\
\text { Cases (Ct Values of } \\
\text { Clinical Samples) }\end{array}$ & $\begin{array}{c}\text { Targets on } \\
\text { SARS-CoV-2 Genome }\end{array}$ & $\begin{array}{l}\text { Sample Considered } \\
\text { Positive with Ct Value } \\
\text { of }\end{array}$ & $\begin{array}{l}\text { Proportion } \\
\text { of Viral RNA } \\
\text { Detection }\end{array}$ & Ct Values & Reference \\
\hline $\begin{array}{l}\text { Diamond Princess cruise ship } \\
\text { during COVID-19 outbreak } \\
\text { (Japan) }\end{array}$ & $\begin{array}{c}\text { Surfaces in cabins of confirmed } \\
\text { cases (330) } \\
\text { Surfaces in cabins of non-cases } \\
(160) \\
\text { Surfaces in shared areas (97) }\end{array}$ & $\mathrm{No}^{*}$ (no Ct values) & Not specified & Not specified & $\begin{array}{c}17.3 \%{ }^{* *} \\
0 \% * * \\
1.0 \% * *\end{array}$ & $\begin{array}{c}26.2-39.0 ; \text { values }<31.0 \text { only } \\
\text { on floors }\end{array}$ & [49] \\
\hline $\begin{array}{l}\text { Rooms of COVID-19 patients } \\
\text { (Singapore) }\end{array}$ & $\begin{array}{l}\text { High-touch surfaces in } \\
\text { accommodation rooms (428) }\end{array}$ & $\mathrm{No}^{*}$ (no Ct values) & RdRp gene & $<35$ & $0.5 \%$ & Not described & [51] \\
\hline $\begin{array}{l}\text { COVID-19 quarantine hotel } \\
\text { (China) }\end{array}$ & Various surfaces (271) & No * (no Ct values) & ORF1ab and $\mathrm{N}$ genes & $<40$ & $6.6 \%$ & 35 (median) & [52] \\
\hline \multirow[t]{2}{*}{$\begin{array}{l}\text { COVID-19 cases in isolation at } \\
\text { home (Germany) }\end{array}$} & Surfaces in 21 households (119) & $\mathrm{No}^{*}$ (no Ct values) & RdRp and E genes & Not described & $3.4 \% * *$ & $>30$ & [50] \\
\hline & & & ORF1ab, $\mathrm{N}$, and $\mathrm{S}$ genes & & $0 \%$ & - & \\
\hline $\begin{array}{l}\text { Clinical microbiology laboratory } \\
\text { (France) }\end{array}$ & Various surfaces (23) & Not applicable & $\begin{array}{l}\text { ORF1ab gene } \\
\mathrm{N} \text { gene } \\
\mathrm{S} \text { gene }\end{array}$ & Not described & $\begin{array}{c}4.3 \% \\
0 \% \\
17.4 \%\end{array}$ & $\begin{array}{c}39.0 \\
- \\
30.3,37.6,38.3,38.8\end{array}$ & [53] \\
\hline $\begin{array}{c}\text { Centralized quarantine hotel } \\
\text { (China) }\end{array}$ & Various surfaces (22) & No * (25.7-33.1) & ORF1ab and $\mathrm{N}$ genes & $<40$ & $36.4 \%$ & 28.8-37.6 (median: 35.6) & [54] \\
\hline $\begin{array}{l}\text { Long-term care facility with } 30 \\
\text { asymptomatic COVID-19 cases } \\
\text { (Greece) }\end{array}$ & Various surfaces (10) & No * (no Ct values) & Not described & Not described & $0 \%$ & - & [40] \\
\hline $\begin{array}{c}\text { Ferryboat during an ongoing } \\
\text { COVID-19 outbreak } \\
\text { investigation (Greece) }\end{array}$ & Various surfaces (9) & $\mathrm{No}^{*}$ (no Ct values) & Not described & Not described & $55.6 \%$ & 26-37 (median: 34) & [40] \\
\hline
\end{tabular}

${ }^{*}$ PCR test results positive; ** no infectious SARS-CoV-2 detected. 
Table 3. Frequency and detection rates of SARS-CoV-2 on public surfaces.

\begin{tabular}{|c|c|c|c|c|c|c|c|}
\hline Setting (Country) & Types of Sampled Surfaces (n) & $\begin{array}{c}\text { Targets on } \\
\text { SARS-CoV-2 Genome }\end{array}$ & $\begin{array}{l}\text { Sample Considered } \\
\text { Positive with Ct Value } \\
\text { of }\end{array}$ & $\begin{array}{l}\text { Proportion of Viral } \\
\text { RNA Detection }\end{array}$ & Ct Values & $\begin{array}{c}\text { Detection Rate of } \\
\text { Infectious SARS-CoV-2 }\end{array}$ & Reference \\
\hline Various public settings (Brazil) & $\begin{array}{c}17 \text { public squares, } 10 \\
\text { universities/schools, } 6 \text { bus } \\
\text { terminals, } 2 \text { public parks, } 1 \\
\text { public market, } 1 \text { shopping mall, } \\
\text { and } 21 \text { other public places (530) }\end{array}$ & $\mathrm{N} 1$ and $\mathrm{N} 2$ genes & $<40$ & $5.5 \% *$ & $\begin{array}{c}29.0-38.1(\mathrm{~N} 1) \\
\text { and } 30.5-39.6 \\
(\mathrm{~N} 2)\end{array}$ & Not described & [11] \\
\hline Bank notes (Bangladesh) & Various bank notes (425) & $\mathrm{N}$ and ORF1b genes & $\leq 36$ & $7.3 \%$ & $\begin{array}{c}\text { Not } \\
\text { described } \\
28.7-40.2(\mathrm{~N} 1)\end{array}$ & Not described & [57] \\
\hline Various public settings (USA) & Various surfaces (348) & N1 or E gene & $<40$ & $8.3 \%$ & $\underset{* * *}{26.6-39.0}(\mathrm{E})$ & Not described & [55] \\
\hline Various public settings (Iran) & $\begin{array}{l}\text { Various high-touch surfaces } \\
\qquad(104)\end{array}$ & $\mathrm{N}$ and ORF1ab genes & $\leq 45$ & $22.1 \%$ & $\begin{array}{c}\text { Not } \\
\text { described }\end{array}$ & Not described & [56] \\
\hline $\begin{array}{l}\text { Public setting next to COVID-19 } \\
\text { hospitalization units (Spain) }\end{array}$ & $\begin{array}{l}\text { Various public high-touch } \\
\text { surfaces (46) }\end{array}$ & RdRp gene & Not described & $0 \%$ & - & Not described & [58] \\
\hline Playgrounds (Israel) & Various surfaces (43) & RdRp, N, and S genes & Not described & $4.7 \%$ & $\begin{array}{c}\text { Not } \\
\text { described }\end{array}$ & Not described & [59] \\
\hline Various public settings (Italy) & $\begin{array}{l}\text { Surfaces in public buildings and } \\
\text { outdoors (41) }\end{array}$ & $\mathrm{RdRp}, \mathrm{N}$, and E genes & $<40$ & $0 \%$ & - & Not described & [27] \\
\hline $\begin{array}{l}\text { High-touch public surfaces } \\
\text { (Saudi Arabia) }\end{array}$ & Various surfaces (22) & Not described & $\leq 45$ & $4.5 \%$ & $\begin{array}{c}\text { Not } \\
\text { described }\end{array}$ & Not described & [30] \\
\hline
\end{tabular}

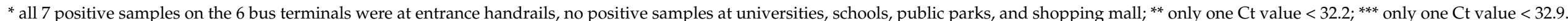


Table 4. Frequency of detection of SARS-CoV-2 RNA on personal protective equipment in the surrounding of COVID-19 patients.

\begin{tabular}{|c|c|c|c|c|c|c|c|}
\hline Setting (Country) & Types of Sampled PPEs (n) & $\begin{array}{c}\text { Evidence for Infectious } \\
\text { Virus in Samples from } \\
\text { Cases (Ct Values of } \\
\text { Clinical Samples) }\end{array}$ & $\begin{array}{c}\text { Targets on } \\
\text { SARS-CoV-2 Genome }\end{array}$ & $\begin{array}{l}\text { Sample Considered } \\
\text { Positive with Ct Value } \\
\text { of }\end{array}$ & $\begin{array}{l}\text { Proportion } \\
\text { of Viral RNA } \\
\text { Detection }\end{array}$ & Ct Values & Reference \\
\hline $\begin{array}{l}\text { Different wards in grade III } \\
\text { hospital (China) }\end{array}$ & $\begin{array}{c}\text { Hand sanitizer dispenser (59), } \\
\text { glove (78), } \\
\text { eye protection, or face shield } \\
\text { (58) }\end{array}$ & No & ORF1ab and $\mathrm{N}$ genes & $<40$ & $\begin{array}{l}20.3 \% \\
15.4 \% \\
1.7 \%\end{array}$ & Not described & [10] \\
\hline $\begin{array}{l}\text { COVID-19 negative-pressure } \\
\text { isolation room (Republic of } \\
\text { Korea) }\end{array}$ & $\begin{array}{c}\text { Different surfaces from PPEs } \\
\text { (133) }\end{array}$ & No & $\mathrm{S}$ and $\mathrm{N}$ genes & $<45$ & $11.3 \%$ * & $\begin{array}{l}\text { Not described; average } \\
\text { RNA concentration between } \\
4.3 \times 10^{2} \text { and } 2.2 \times 10^{4}\end{array}$ & {$[60]$} \\
\hline $\begin{array}{l}\text { COVID-19 isolation room } \\
\text { (Singapore) }\end{array}$ & $\begin{array}{l}\text { Different surfaces from PPEs } \\
\qquad(90)\end{array}$ & $\mathrm{No}^{* *}(28.8-30.9)$ & RdRp and $E$ genes & Not described & $0 \%$ & - & {$[61]$} \\
\hline $\begin{array}{l}\text { Rooms with non-severe } \\
\text { COVID-19 patients (China) }\end{array}$ & Different surfaces of PPE (55) & $\mathrm{No}^{* *}(20.8-37.9)$ & ORF1 $\mathrm{ab}$ and $\mathrm{N}$ genes & $<40$ & $0 \%$ & - & [62] \\
\hline $\begin{array}{l}\text { University hospital during } \\
\text { COVID-19 pandemic (England) }\end{array}$ & $\begin{array}{l}\text { Surfaces of powered air } \\
\text { purifying respirators (40) }\end{array}$ & No & ORF1ab and E genes & Not described & $0 \%$ & - & [63] \\
\hline $\begin{array}{l}\text { ICU and general ward with } \\
\text { COVID-19 patients (China) }\end{array}$ & $\begin{array}{c}\text { Shoe sole (9), } \\
\text { glove (7), } \\
\text { sleeve cuff (9), and } \\
\text { face shield (9) }\end{array}$ & No & ORF1 $\mathrm{ab}$ and $\mathrm{N}$ genes & Not described & $\begin{array}{c}33.3 \% \\
14.3 \% * * * \\
11.1 \% \\
0 \%\end{array}$ & $\begin{array}{l}\text { Not described; average } \\
\text { RNA concentration between } \\
2.9 \times 10^{3} \text { and } 3.2 \times 10^{4}\end{array}$ & [19] \\
\hline $\begin{array}{l}\text { COVID-19 treatment centre for } \\
\text { patients after tracheostomy } \\
\text { (China) }\end{array}$ & $\begin{array}{c}\text { Powered air-purifying } \\
\text { respirators (8), } \\
\text { glove (8), } \\
\text { gowns (8), and } \\
\text { shoes (8) }\end{array}$ & No & ORF1ab and NP genes & $<40$ & $0 \%$ & - & [17] \\
\hline Emergency department (France) & $\begin{array}{c}\text { Different surfaces from PPEs } \\
(16)\end{array}$ & No & ORF1ab and E genes & Not described & $6.3 \%$ & 38.4 & [46] \\
\hline $\begin{array}{l}\text { COVID-19 isolation room } \\
\text { (Singapore) }\end{array}$ & $\begin{array}{c}\text { Different surfaces from PPEs } \\
(10)\end{array}$ & $\mathrm{No}^{* *}(23.2-35.3)$ & RdRp and E genes & $\leq 45$ & $\begin{array}{l}10 \% \text { (front of } \\
\text { shoes) }\end{array}$ & 39.0 & [47] \\
\hline $\begin{array}{l}\text { COVID-19 isolation room } \\
\text { (Singapore) }\end{array}$ & $\begin{array}{l}\text { Face shield (1), } \\
\text { N95 mask (1), and } \\
\text { waterproof gown (1) }\end{array}$ & No ** $(13.7-15.6)$ & RdRp and $E$ genes & $<36$ & $\begin{array}{l}0 \% \\
0 \% \\
0 \%\end{array}$ & - & [32] \\
\hline
\end{tabular}




\section{Discussion}

This literature review shows that infectious SARS-CoV-2 is rarely detected on surfaces in the areas surrounding confirmed COVID-19 patients, mainly when a patient is coughing during sampling. In addition, viral RNA can be detected in variable proportions but mostly with Ct values $>30$ suggesting a low viral RNA load. It is therefore assumed that surfaces in hospitals have probably no relevance as a potential source for transmission, especially when regular disinfection and cleaning is done as recommended by the WHO [64]. Similar findings were described for SARS-CoV-2 from public surfaces and PPE surfaces. The results are in line with very low detection rates of infectious influenza virus in 90 households $(0 \%)$ or on 671 frequently touched surfaces in hospital rooms with confirmed influenza infection $(0.3 \%)[65,66]$.

The CDC has recently published a science brief on the possible transmission of SARS$\mathrm{CoV}-2$ from surfaces and concluded that it is possible for people to be infected through contact with contaminated surfaces or objects (fomites), but the risk is generally considered to be low [67]. Based on different quantitative microbial risk assessments, it was considered to be generally less than 1 in 10,000 [55,68]. Under low viral bioburden conditions $\left(<1\right.$ genome copy per $\left.\mathrm{cm}^{2}\right)$, it was described to be below 1:1,000,000 [69].

The major limitation of the currently available studies is the lack of evidence that COVID-19 patients in healthcare settings were still shedding infectious SARS-CoV-2, as only viral RNA was detected for confirmation of the diagnosis. It has been described that infectious SARS-CoV-2 is typically detected for 7 days in respiratory tract samples, whereas viral RNA may be found for up to 28 days after beginning of the symptoms [70,71]. If patients do not shed infectious SARS-CoV-2 anymore but only viral RNA, it would be plausible to detect mainly viral RNA on surfaces and only rarely infectious virus. Future research on surface contamination need to also address the question of whether the patient carries infectious SARS-CoV-2 at the time of surface sampling. Another limitation is that the incidence of COVID-19 in the various public settings described in the studies is variable and often not known.

Whereas regular and targeted disinfection of surfaces in the areas surrounding critically ill patients in healthcare settings remains an important measure to control the spread not only of viruses but also bacteria and fungi [72], there is currently no evidence that suggest an important role of fomite transmission in the public setting. The available data do not support the necessity of regular disinfection procedures of public surfaces as currently observed in many countries. WHO still recommends reducing potential for COVID-19 virus contamination in non-healthcare settings, such as in the home, office, schools, gyms, or restaurants [73]. High-touch surfaces in these non-health care settings should be identified for priority disinfection. These include door and window handles, kitchen and food preparation areas, counter tops, bathroom surfaces, toilets and taps, touchscreen personal devices, personal computer keyboards, and work surfaces [73]. CDC advocates the cleaning and disinfection of surfaces in community facilities only after persons with suspected or confirmed COVID-19 have been in the facility [74]. The Robert Koch Institute in Germany describes cleaning of surfaces as the preferred option because it is still unknown if a surface disinfection outside healthcare facilities is overall necessary. A routine disinfection at home or in public places, including surfaces with frequent hand contacts, is currently not recommended [75]. In public settings, the contamination with high-titre infectious virus is even less likely compared to the immediate surrounding of confirmed COVID-19 cases in healthcare settings or at home. Viral contamination can possibly occur in the unlikely event of a symptomatic or an asymptomatic COVID-19 case near the surface. However, unlike in patient rooms or the domestic setting, it is not expected that there is a permanent presence of a potential virus source next to the surface.

A possible transmission from surfaces could occur via transiently contaminated hands after contact with a virus-contaminated surface followed by a hand-nose or hand-mouth contact. Several studies have analysed the likelihood of fomite transmission for respiratory viruses. One study highlighted the importance of aerosols for rhinovirus transmission 
in contrast to a neglectable role for surfaces. In this study, two groups of men played poker, one group sick with the common cold and the other group healthy. The healthy group was exposed to infectious virus aerosols simply by being in the same room with the sick group; however, they were restrained so that participants could not touch their faces. Cards and chips used in the poker game were transferred to a group of healthy men to play with, and they were instructed to touch their faces frequently. Interestingly, the aerosol-exposed group got sick, while the surfaces-exposed group did not [76]. Another study could show that, on hands, only a small fraction of infectious virus is usually found after contact with artificially contaminated surfaces, such as $1.5 \%$ with parainfluenza virus and $0.7 \%$ with rhinovirus [77]. In addition, only a small fraction of the viral load can be transferred from contaminated hands to a surface $(0 \%$ with parainfluenza virus and $0.9 \%$ with rhinovirus) [77]. Importantly, the risk of disease transmission by hand contact with a contaminated surface followed by a single hand-nose-contact is for rhinovirus low $(0.0486 \%)$ and for influenza virus very low $(0.0000000256 \%)$ [78]. Of note, seasonality of virus transmission should be considered when interpreting these results as some factors including humidity can directly influence aerosol stability. Under tropic conditions (warm and humid climates), aerosols or droplets evaporate less water and therefore readily settle on surfaces, which could favour fomite transmission as hypothesized for influenza viruses [79]. In addition, it was shown under experimental laboratory conditions at $24{ }^{\circ} \mathrm{C}$ that the half-life of SARS-CoV-2 infectivity is $15 \mathrm{~h}$ at $20 \%$ relative humidity, $12 \mathrm{~h}$ at $40 \%$ humidity, and $9 \mathrm{~h}$ at $60 \%$ humidity, suggesting a longer persistence of SARS-CoV-2 in dry air [80]. In addition, viral half-life was shorter at $35{ }^{\circ} \mathrm{C}$ compared to $24{ }^{\circ} \mathrm{C}$ [81]. Comparative data at $10{ }^{\circ} \mathrm{C}$ and $22^{\circ} \mathrm{C}$ at different relative humidities show a longer persistence of SARS-CoV-2 at the lower temperature [81]. Nevertheless, hand washing is recommended for the public especially when returning home because the hands may also get contaminated from other people who are coughing or sneezing [82].

Especially in the public setting, as exemplified by a study analysing bus terminals in Brazil, it was interesting to see that all seven positive samples (RNA detection) were found at entrance handrails of the bus terminals. This may be explained by droplets coming from viral carriers close to the handrails. It may also be explained by SARS-CoV-2-positive passengers wearing face masks during coughing, sneezing, or talking because SARS-CoV2 RNA may be found on the outer surface of a face mask. By touching the face mask, the hands may get contaminated, which may finally result in a handrail contamination. The corresponding Ct values, however, were so high that the RNA-positive handrails are probably not a relevant source of transmission because only a fraction of the virus remains on the hands after a hand-surface contact.

Cleaning of surfaces by a single, two second wipe has been described to reduce infectious coronavirus by $2.4 \log _{10}$ [83]. Similar results $\left(2.5 \log _{10}\right)$ were obtained with a five second single wipe against ebolavirus [84]. These results suggest that in most settings, a simple cleaning procedure with a moist wipe will be sufficient to control the very low risk attributed to public surfaces.

A health benefit of regular disinfection of public surfaces is unlikely, given the currently assumed low transmission risk via this route. Furthermore, it is important to note that regular disinfection of surfaces also carries costs, such as reducing the diversity of the microbiome and increasing the diversity of bacterial resistance genes [85]. Microbiome diversity on surfaces is especially important for babies to ensure a balanced and healthy gut microflora [86]. An increased diversity of resistance genes enhances the occurrence of multi-resistant bacteria, which is a major burden for healthcare in Europe [87] and elsewhere. Permanent exposure of bacteria to subinhibitory concentrations of some biocidal agents used for surface disinfection can cause a strong, adaptive cellular response resulting in a stable tolerance to the biocidal agents and rarely, in a few species, in a new antibiotic resistance [88]. The daily number of calls to U.S. poison centres has substantially increased in 2020, mainly for bleach $(+62.1 \%)$ and other disinfectants $(+36.7 \%)$. Inhalation represented the largest percentage increase among all exposure routes $(+35.3 \%$ for cleaners like bleach; 
$+108.8 \%$ for all other disinfectants) [89]. The non-targeted, regular surface disinfection in many public places will probably have no health benefit but may have some negative side effects, similar to the broad non-targeted use of triclosan in the past [90].

A relevant question, however, remains open in this context and will hopefully be addressed in future research. To our knowledge, it has not been described how long SARS-CoV-2 remains infectious on surfaces when left in the respiratory tract secretions of confirmed COVID-19 patients. All experiments were so far done with laboratory-based, cultured SARS-CoV-2. It may well be that SARS-CoV-2 in body fluids is inactivated much faster than SARS-CoV-2 in stock solutions, as suggested by experiments with faeces [91].

\section{Conclusions}

Currently, available data do not support surfaces as a relevant source of SARS-CoV-2 transmission. In healthcare settings with confirmed COVID-19 cases, regular surface disinfection remains a precautionary element of infection control. In public settings, however, the associated risks and harms of regular surface disinfection probably outweigh the expected health benefits. Future studies should focus on sampling surfaces for infectious SARS-CoV-2 and better combining epidemiological and environmental data to evaluate the relevance of surfaces as a possible source for SARS-CoV-2 transmission.

Author Contributions: G.K. performed the literature search and prepared the first draft of the manuscript. S.P., E.G., and E.S. reviewed the data, provided conceptual ideas for the discussion, and edited the manuscript. All authors have read and agreed to the published version of the manuscript.

Funding: This research received no external funding.

Institutional Review Board Statement: Not applicable.

Informed Consent Statement: Not applicable.

Data Availability Statement: Not applicable.

Conflicts of Interest: G.K. has received personal fees from Schumacher GmbH, Germany, for presentation and consultation. S.P., E.G., and E.S. have no conflict of interest.

\section{References}

1. Kampf, G.; Todt, D.; Pfaender, S.; Steinmann, E. Persistence of coronaviruses on inanimate surfaces and its inactivation with biocidal agents. J. Hosp. Infect. 2020, 104, 246-251. [CrossRef] [PubMed]

2. Riddell, S.; Goldie, S.; Hill, A.; Eagles, D.; Drew, T.W. The effect of temperature on persistence of SARS-CoV-2 on common surfaces. Virol. J. 2020, 17, 145. [CrossRef]

3. Van Doremalen, N.; Bushmaker, T.; Morris, D.H.; Holbrook, M.G.; Gamble, A.; Williamson, B.N.; Tamin, A.; Harcourt, J.L.; Thornburg, N.J.; Gerber, S.I.; et al. Aerosol and surface stability of SARS-CoV-2 as compared with SARS-CoV-1. N. Engl. J. Med. 2020, 382, 1564-1567. [CrossRef]

4. Eccles, R. Respiratory mucus and persistence of virus on surfaces. J. Hosp. Infect. 2020, 105, 350. [CrossRef] [PubMed]

5. Goldman, E. Exaggerated risk of transmission of COVID-19 by fomites. Lancet Infect. Dis. 2020, 20, 892-893. [CrossRef]

6. Zhou, J.; Otter, J.A.; Price, J.R.; Cimpeanu, C.; Garcia, D.M.; Kinross, J.; Boshier, P.R.; Mason, S.; Bolt, F.; Holmes, A.H.; et al. Investigating SARS-CoV-2 surface and air contamination in an acute healthcare setting during the peak of the COVID-19 pandemic in London. Clin. Infect. Dis. 2021, 72. [CrossRef]

7. Ahn, J.Y.; An, S.; Sohn, Y.; Cho, Y.; Hyun, J.H.; Baek, Y.J.; Kim, M.H.; Jeong, S.J.; Kim, J.H.; Ku, N.S.; et al. Environmental contamination in the isolation rooms of COVID-19 patients with severe pneumonia requiring mechanical ventilation or high-flow oxygen therapy. J. Hosp. Infect. 2020, 106, 570-576. [CrossRef]

8. Kampf, G.; Lemmen, S.; Suchomel, M. Ct values and infectivity of SARS-CoV-2 on surfaces. Lancet Infect. Dis 2021, 21. [CrossRef]

9. Marotz, C.; Belda-Ferre, P.; Ali, F.; Das, P.; Huang, S.; Cantrel, K.; Jiang, L.; Martino, C.; Diner, R.; Rahman, G.; et al. Microbial context predicts SARS-CoV-2 prevalence in patients and the hospital built environment. medRxiv 2020. [CrossRef]

10. Ye, G.; Lin, H.; Chen, S.; Wang, S.; Zeng, Z.; Wang, W.; Zhang, S.; Rebmann, T.; Li, Y.; Pan, Z.; et al. Environmental contamination of SARS-CoV-2 in healthcare premises. J. Infect. 2020, 81, e1-e5. [CrossRef]

11. Abrahão, J.S.; Sacchetto, L.; Rezende, I.M.; Rodrigues, R.A.L.; Crispim, A.P.C.; Moura, C.; Mendonça, D.C.; Reis, E.; Souza, F.; Oliveira, G.F.G.; et al. Detection of SARS-CoV-2 RNA on public surfaces in a densely populated urban area of brazil: A potential tool for monitoring the circulation of infected patients. Sci. Total Environ. 2021, 766, 142645. [CrossRef] [PubMed] 
12. Moore, G.; Rickard, H.; Stevenson, D.; Aranega-Bou, P.; Pitman, J.; Crook, A.; Davies, K.; Spencer, A.; Burton, C.; Easterbrook, L.; et al. Detection of SARS-CoV-2 within the healthcare environment: A multi-centre study conducted during the first wave of the COVID-19 outbreak in england. J. Hosp. Infect. 2021, 108, 189-196. [CrossRef]

13. Zhou, L.; Yao, M.; Zhang, X.; Hu, B.; Li, X.; Chen, H.; Zhang, L.; Liu, Y.; Du, M.; Sun, B.; et al. Breath-, air- and surface-borne SARS-CoV-2 in hospitals. J. Aerosol Sci. 2020, 152, 105693. [CrossRef] [PubMed]

14. Chia, P.Y.; Coleman, K.K.; Tan, Y.K.; Ong, S.W.X.; Gum, M.; Lau, S.K.; Lim, X.F.; Lim, A.S.; Sutjipto, S.; Lee, P.H.; et al. Detection of air and surface contamination by SARS-CoV-2 in hospital rooms of infected patients. Nat. Commun. 2020, 11, 2800. [CrossRef] [PubMed]

15. Wu, S.; Wang, Y.; Jin, X.; Tian, J.; Liu, J.; Mao, Y. Environmental contamination by SARS-CoV-2 in a designated hospital for coronavirus disease 2019. Am. J. Infect. Control 2020, 48, 910-914. [CrossRef] [PubMed]

16. Ong, S.W.X.; Lee, P.H.; Tan, Y.K.; Ling, L.M.; Ho, B.C.H.; Ng, C.G.; Wang, D.L.; Tan, B.H.; Leo, Y.S.; Ng, O.T.; et al. Environmental contamination in a COVID-19 intensive care unit (ICU)—What is the risk? Infect. Control Hosp. Epidemiol. 2021, 42, 1-9. [CrossRef] [PubMed]

17. Xu, K.; Zhang, X.H.; Long, X.B.; Lu, X.; Liu, Z. An environmental study of tracheostomy on eight COVID-19 patients. J. Otolaryngol. Head Neck Surg. 2021, 50, 3. [CrossRef]

18. Lei, H.; Ye, F.; Liu, X.; Huang, Z.; Ling, S.; Jiang, Z.; Cheng, J.; Huang, X.; Wu, Q.; Wu, S.; et al. SARS-CoV-2 environmental contamination associated with persistently infected COVID-19 patients. Influenza Other Respir. Viruses 2020, 14, 688-699. [CrossRef]

19. Guo, Z.D.; Wang, Z.Y.; Zhang, S.F.; Li, X.; Li, L.; Li, C.; Cui, Y.; Fu, R.B.; Dong, Y.Z.; Chi, X.Y.; et al. Aerosol and surface distribution of severe acute respiratory syndrome coronavirus 2 in hospital wards, Wuhan, China, 2020. Emerg. Infect. Dis. 2020, 26, 1583-1591. [CrossRef]

20. Ryu, B.H.; Cho, Y.; Cho, O.H.; Hong, S.I.; Kim, S.; Lee, S. Environmental contamination of SARS-CoV-2 during the COVID-19 outbreak in South Korea. Am. J. Infect. Control 2020, 48, 875-879. [CrossRef]

21. Wang, H.; Mo, P.; Li, G.; Chen, P.; Liu, J.; Wang, H.; Wang, F.; Zhang, Y.; Zhao, Q. Environmental virus surveillance in the isolation ward of COVID-19. J. Hosp. Infect. 2020, 105, 373-374. [CrossRef]

22. Lee, S.E.; Lee, D.Y.; Lee, W.G.; Kang, B.; Jang, Y.S.; Ryu, B.; Lee, S.; Bahk, H.; Lee, E. Detection of novel coronavirus on the surface of environmental materials contaminated by COVID-19 patients in the Republic of Korea. Osong Public Health Res. Perspect. 2020, 11, 128-132. [CrossRef]

23. Escudero, D.; Boga, J.A.; Fernández, J.; Forcelledo, L.; Balboa, S.; Albillos, R.; Astola, I.; García-Prieto, E.; Álvarez-Argüelles, M.E.; Martín, G.; et al. SARS-CoV-2 analysis on environmental surfaces collected in an intensive care unit: Keeping ernest shackleton's spirit. Intensive Care Med. Exp. 2020, 8, 68. [CrossRef]

24. Ben-Shmuel, A.; Brosh-Nissimov, T.; Glinert, I.; Bar-David, E.; Sittner, A.; Poni, R.; Cohen, R.; Achdout, H.; Tamir, H.; YahalomRonen, Y.; et al. Detection and infectivity potential of severe acute respiratory syndrome coronavirus 2 (SARS-CoV-2) environmental contamination in isolation units and quarantine facilities. Clin. Microbiol. Infect. 2020, 26, 1658-1662. [CrossRef]

25. Wang, J.; Feng, H.; Zhang, S.; Ni, Z.; Ni, L.; Chen, Y.; Zhuo, L.; Zhong, Z.; Qu, T. SARS-CoV-2 RNA detection of hospital isolation wards hygiene monitoring during the coronavirus disease 2019 outbreak in a chinese hospital. Int. J. Infect. Dis. IJID Off. Publ. Int. Soc. Infect. Dis. 2020, 94, 103-106.

26. Dargahi, A.; Jeddi, F.; Vosoughi, M.; Karami, C.; Hadisi, A.; Ahamad Mokhtari, S.; Ghobadi, H.; Alighadri, M.; Haghighi, S.B.; Sadeghi, H. Investigation of SARS-CoV-2 virus in environmental surface. Environ. Res. 2021, 195, 110765. [CrossRef] [PubMed]

27. Piana, A.; Colucci, M.E.; Valeriani, F.; Marcolongo, A.; Sotgiu, G.; Pasquarella, C.; Margarucci, L.M.; Petrucca, A.; Gianfranceschi, G.; Babudieri, S.; et al. Monitoring COVID-19 transmission risks by quantitative real-time pcr tracing of droplets in hospital and living environments. mSphere 2021, 6. [CrossRef]

28. Hu, X.; Ni, W.; Wang, Z.; Ma, G.; Pan, B.; Dong, L.; Gao, R.; Jiang, F. The distribution of SARS-CoV-2 contamination on the environmental surfaces during incubation period of COVID-19 patients. Ecotoxicol. Environ. Saf. 2020, 208, 111438. [CrossRef] [PubMed]

29. Orenes-Piñero, E.; Baño, F.; Navas-Carrillo, D.; Moreno-Docón, A.; Marín, J.M.; Misiego, R.; Ramírez, P. Evidences of SARS-CoV-2 virus air transmission indoors using several untouched surfaces: A pilot study. Sci. Total Environ. 2021, 751, 142317. [CrossRef] [PubMed]

30. Elbadawy, H.M.; Khattab, A.; Alalawi, A.; Dakilallah Aljohani, F.; Sundogji, H.; Mahmoud, A.S.; Abouzied, M.; Eltahir, H.M.; Alahmadey, Z.; Bahashwan, S.; et al. The detection of SARS-CoV-2 in outpatient clinics and public facilities during the COVID-19 pandemic. J. Med. Virol. 2021, 93, 2955-2961. [CrossRef] [PubMed]

31. Colaneri, M.; Seminari, E.; Piralla, A.; Zuccaro, V.; Filippo, A.D.; Baldanti, F.; Bruno, R.; Mondelli, M.U. Lack of SARS-CoV-2 RNA environmental contamination in a tertiary referral hospital for infectious diseases in northern Italy. J. Hosp. Infect. 2020, 105, 474-476. [CrossRef]

32. Yung, C.F.; Kam, K.Q.; Wong, M.S.Y.; Maiwald, M.; Tan, Y.K.; Tan, B.H.; Thoon, K.C. Environment and personal protective equipment tests for SARS-CoV-2 in the isolation room of an infant with infection. Ann. Intern. Med. 2020, 173, 240-242. [CrossRef]

33. Cheng, V.C.C.; Wong, S.C.; Chen, J.H.K.; Yip, C.C.Y.; Chuang, V.W.M.; Tsang, O.T.Y.; Sridhar, S.; Chan, J.F.W.; Ho, P.L.; Yuen, K.Y. Escalating infection control response to the rapidly evolving epidemiology of the coronavirus disease 2019 (COVID-19) due to SARS-CoV-2 in Hong Kong. Infect. Control Hosp. Epidemiol. 2020, 41, 493-498. [CrossRef] [PubMed] 
34. Liang En Ian, W.; Sim, X.Y.J.; Conceicao, E.P.; Aung, M.K.; Tan, K.Y.; Ko, K.K.K.; Wong, H.M.; Wijaya, L.; Tan, B.H.; Venkatachalam, I.; et al. Containing COVID-19 outside the isolation ward: The impact of an infection control bundle on environmental contamination and transmission in a cohorted general ward. Am. J. Infect. Control 2020, 48, 1056-1061.

35. Cheng, V.C.; Wong, S.C.; Chan, V.W.; So, S.Y.; Chen, J.H.; Yip, C.C.; Chan, K.H.; Chu, H.; Chung, T.W.; Sridhar, S.; et al. Air and environmental sampling for SARS-CoV-2 around hospitalized patients with coronavirus disease 2019 (COVID-19). Infect. Control Hosp. Epidemiol. 2020, 41, 1258-1265. [CrossRef] [PubMed]

36. Kim, U.J.; Lee, S.Y.; Lee, J.Y.; Lee, A.; Kim, S.E.; Choi, O.J.; Lee, J.S.; Kee, S.J.; Jang, H.C. Air and environmental contamination caused by COVID-19 patients: A multi-center study. J. Korean Med. Sci. 2020, 35, e332. [CrossRef]

37. Tan, L.; Ma, B.; Lai, X.; Han, L.; Cao, P.; Zhang, J.; Fu, J.; Zhou, Q.; Wei, S.; Wang, Z.; et al. Air and surface contamination by SARS-CoV-2 virus in a tertiary hospital in Wuhan, China. Int. J. Infect. Dis. IJID Off. Publ. Int. Soc. Infect. Dis. 2020, 99, 3-7. [CrossRef] [PubMed]

38. Su, W.L.; Hung, P.P.; Lin, C.P.; Chen, L.K.; Lan, C.C.; Yang, M.C.; Peng, M.Y.; Chao, Y.C. Masks and closed-loop ventilators prevent environmental contamination by COVID-19 patients in negative-pressure environments. J. Microbiol. Immunol. Infect. 2020, 54, 81-84. [CrossRef]

39. Shah, M.R.; Jan, I.; Johns, J.; Singh, K.; Kumar, P.; Belarmino, N.; Saggiomo, K.J.; Hayes, C.; Washington, K.; Toppmeyer, D.L.; et al. SARS-CoV-2 nosocomial infection: Real-world results of environmental surface testing from a large tertiary cancer center. Cancer 2021. [CrossRef] [PubMed]

40. Mouchtouri, V.A.; Koureas, M.; Kyritsi, M.; Vontas, A.; Kourentis, L.; Sapounas, S.; Rigakos, G.; Petinaki, E.; Tsiodras, S.; Hadjichristodoulou, C. Environmental contamination of SARS-CoV-2 on surfaces, air-conditioner and ventilation systems. Int. J. Hyg. Environ. Health 2020, 230, 113599. [CrossRef]

41. Jerry, J.; O'Regan, E.; O'Sullivan, L.; Lynch, M.; Brady, D. Do established infection prevention and control measures prevent spread of SARS-CoV-2 to the hospital environment beyond the patient room? J. Hosp. Infect. 2020, 105, 589-592. [CrossRef] [PubMed]

42. Colaneri, M.; Seminari, E.; Novati, S.; Asperges, E.; Biscarini, S.; Piralla, A.; Percivalle, E.; Cassaniti, I.; Baldanti, F.; Bruno, R.; et al. Severe acute respiratory syndrome coronavirus 2 RNA contamination of inanimate surfaces and virus viability in a health care emergency unit. Clin. Microbiol. Infect. 2020, 26, 1094.e1091-1094.e1095. [CrossRef] [PubMed]

43. Wei, L.; Lin, J.; Duan, X.; Huang, W.; Lu, X.; Zhou, J.; Zong, Z. Asymptomatic COVID-19 patients can contaminate their surroundings: An environment sampling study. mSphere 2020, 5, e00442-20. [CrossRef] [PubMed]

44. D'Accolti, M.; Soffritti, I.; Passaro, A.; Zuliani, G.; Antonioli, P.; Mazzacane, S.; Manfredini, R.; Caselli, E. SARS-CoV-2 RNA contamination on surfaces of a COVID-19 ward in a hospital of northern Italy: What risk of transmission? Eur. Rev. Med. Pharmacol. Sci. 2020, 24, 9202-9207. [PubMed]

45. Lomont, A.; Boubaya, M.; Khamis, W.; Deslandes, A.; Cordel, H.; Seytre, D.; Alloui, C.; Malaure, C.; Bonnet, N.; Carbonnelle, E.; et al. Environmental contamination related to SARS-CoV-2 in ICU patients. ERJ Open Res. 2020, 6. [CrossRef]

46. Peyrony, O.; Ellouze, S.; Fontaine, J.P.; Thegat-Le Cam, M.; Salmona, M.; Feghoul, L.; Mahjoub, N.; Mercier-Delarue, S.; Gabassi, A.; Delaugerre, C.; et al. Surfaces and equipment contamination by severe acute respiratory syndrome coronavirus 2 (SARS-CoV-2) in the emergency department at a university hospital. Int. J. Hyg. Environ. Health 2020, 230, 113600. [CrossRef] [PubMed]

47. Ong, S.W.X.; Tan, Y.K.; Chia, P.Y.; Lee, T.H.; Ng, O.T.; Wong, M.S.Y.; Marimuthu, K. Air, surface environmental, and personal protective equipment contamination by severe acute respiratory syndrome coronavirus 2 (SARS-CoV-2) from a symptomatic patient. JAMA 2020, 323, 1610-1612. [CrossRef]

48. Hofmaenner, D.A.; Wendel Garcia, P.D.; Duvnjak, B.; Chakrakodi, B.; Maier, J.D.; Huber, M.; Huder, J.; Wolfensberger, A.; Schreiber, P.W.; Schuepbach, R.A.; et al. Bacterial but no SARS-CoV-2 contamination after terminal disinfection of tertiary care intensive care units treating COVID-19 patients. Antimicrob. Resist. Infect. Control 2021, 10, 11. [CrossRef]

49. Yamagishi, T.; Ohnishi, M.; Matsunaga, N.; Kakimoto, K.; Kamiya, H.; Okamoto, K.; Suzuki, M.; Gu, Y.; Sakaguchi, M.; Tajima, T.; et al. Environmental sampling for severe acute respiratory syndrome coronavirus 2 during a COVID-19 outbreak on the diamond princess cruise ship. J. Infect. Dis. 2020, 222, 1098-1102. [CrossRef]

50. Döhla, M.; Wilbring, G.; Schulte, B.; Kümmerer, B.M.; Diegmann, C.; Sib, E.; Richter, E.; Haag, A.; Engelhart, S.; Eis-Hübinger, A.M.; et al. SARS-CoV-2 in environmental samples of quarantined households. medRxiv 2020. [CrossRef]

51. Wong, J.C.C.; Hapuarachchi, H.C.; Arivalan, S.; Tien, W.P.; Koo, C.; Mailepessov, D.; Kong, M.; Nazeem, M.; Lim, M.; Ng, L.C. Environmental contamination of SARS-CoV-2 in a non-healthcare setting. Int. J. Environ. Res. Public Health 2020, 18, 117. [CrossRef]

52. Liu, J.; Liu, J.; He, Z.; Yang, Z.; Yuan, J.; Wu, H.; Zhu, P.; Fu, X.; Lin, Y.; Zhang, Y.; et al. Duration of SARS-CoV-2 positive in quarantine room environments: A perspective analysis. Int. J. Infect. Dis. IJID Off. Publ. Int. Soc. Infect. Dis. 2021, 105, 68-74.

53. Bloise, I.; Gómez-Arroyo, B.; García-Rodríguez, J. Detection of SARS-CoV-2 on high-touch surfaces in a clinical microbiology laboratory. J. Hosp. Infect. 2020, 105, 784-786. [CrossRef] [PubMed]

54. Jiang, F.C.; Jiang, X.L.; Wang, Z.G.; Meng, Z.H.; Shao, S.F.; Anderson, B.D.; Ma, M.J. Detection of severe acute respiratory syndrome coronavirus 2 RNA on surfaces in quarantine rooms. Emerg. Infect. Dis. 2020, 26, 2162-2164. [CrossRef] [PubMed]

55. Harvey, A.P.; Fuhrmeister, E.R.; Cantrell, M.E.; Pitol, A.K.; Swarthout, J.M.; Powers, J.E.; Nadimpalli, M.L.; Julian, T.R.; Pickering, A.J. Longitudinal monitoring of SARS-CoV-2 RNA on high-touch surfaces in a community setting. Environ. Sci. Technol. Lett. 2021, 8, 168-175. [CrossRef] 
56. Gholipour, S.; Nikaeen, M.; Mohammadi Manesh, R.; Aboutalebian, S.; Shamsizadeh, Z.; Nasri, E.; Mirhendi, H. Severe acute respiratory syndrome coronavirus 2 (SARS-CoV-2) contamination of high-touch surfaces in field settings. Biomed. Environ. Sci. BES 2020, 33, 925-929. [PubMed]

57. Akter, S.; Roy, P.C.; Ferdaus, A.; Ibnat, H.; Alam, A.; Nigar, S.; Jahid, I.K.; Hossain, M.A. Prevalence and stability of SARS-CoV-2 RNA on Bangladeshi banknotes. Sci. Total Environ. 2021, 779, 146133. [CrossRef]

58. Gavaldà-Mestre, L.; Ramírez-Tarruella, D.; Gutiérrez-Milla, C.; Guillamet-Roig, F.; Orriols-Ramos, R.; Tisner, S.R.; Pàrraga-Niño, N. Nondetection of SARS-CoV-2 on high-touch surfaces of public areas next to COVID-19 hospitalization units. Am. J. Infect. Control 2021. [CrossRef]

59. Kozer, E.; Rinott, E.; Kozer, G.; Bar-Haim, A.; Benveniste-Levkovitz, P.; Klainer, H.; Perl, S.; Youngster, I. Presence of SARS-CoV-2 RNA on playground surfaces and water fountains. Epidemiol. Infect. 2021, 149, e67. [CrossRef]

60. Jung, J.; Kim, J.Y.; Bae, S.; Cha, H.H.; Kim, E.O.; Kim, M.J.; Kim, S.H. Contamination of personal protective equipment by SARS-CoV-2 during routine care of patients with mild COVID-19. J. Infect. 2020, 81, e165-e167. [CrossRef]

61. Ong, S.W.X.; Tan, Y.K.; Sutjipto, S.; Chia, P.Y.; Young, B.E.; Gum, M.; Lau, S.K.; Chan, M.; Vasoo, S.; Mendis, S.; et al. Absence of contamination of personal protective equipment (PPE) by severe acute respiratory syndrome coronavirus 2 (SARS-CoV-2). Infect. Control Hosp. Epidemiol. 2020, 41, 614-616. [CrossRef] [PubMed]

62. Wei, L.; Huang, W.; Lu, X.; Wang, Y.; Cheng, L.; Deng, R.; Long, H.; Zong, Z. Contamination of SARS-CoV-2 in patient surroundings and on personal protective equipment in a non-ICU isolation ward for COVID-19 patients with prolonged pcr positive status. Antimicrob. Resist. Infect. Control 2020, 9, 167. [CrossRef] [PubMed]

63. Chakladar, A.; Jones, C.G.; Siu, J.; Hassan-Ibrahim, M.O.; Khan, M. Microbial contamination of powered air purifying respirators (PAPR) used by healthcare staff during the COVID-19 pandemic: An in situ microbiological study. Am. J. Infect. Control 2021. [CrossRef] [PubMed]

64. WHO. Infection Prevention and Control during Health Care When Novel Coronavirus (NCOV) Infection Is Suspected. Interim Guidance. 19 March 2020. Available online: https://www.who.int/publications-detail/infection-prevention-and-control-duringhealth-care-when-novel-coronavirus-(ncov)-infection-is-suspected-20200125 (accessed on 16 April 2020).

65. Simmerman, J.M.; Suntarattiwong, P.; Levy, J.; Gibbons, R.V.; Cruz, C.; Shaman, J.; Jarman, R.G.; Chotpitayasunondh, T. Influenza virus contamination of common household surfaces during the 2009 influenza a (H1N1) pandemic in Bangkok, Thailand: Implications for contact transmission. Clin. Infect. Dis. Off. Publ. Infect. Dis. Soc. Am. 2010, 51, 1053-1061. [CrossRef] [PubMed]

66. Killingley, B.; Greatorex, J.; Digard, P.; Wise, H.; Garcia, F.; Varsani, H.; Cauchemez, S.; Enstone, J.E.; Hayward, A.; Curran, M.D.; et al. The environmental deposition of influenza virus from patients infected with influenza a (H1N1)pdm09: Implications for infection prevention and control. J. Infect. Public Health 2016, 9, 278-288. [CrossRef] [PubMed]

67. CDC. Science Brief: SARS-CoV-2 and Surface (Fomite) Transmission for Indoor Community Environments. 5 April 2021. Available online: https:/ / www.cdc.gov/coronavirus/2019-ncov/more/science-and-research/surface-transmission.html (accessed on 5 May 2020).

68. Pitol, A.K.; Julian, T.R. Community transmission of SARS-CoV-2 by surfaces: Risks and risk reduction strategies. Environ. Sci. Technol. Lett. 2021, 8, 263-269. [CrossRef]

69. Wilson, A.M.; Weir, M.H.; Bloomfield, S.F.; Scott, E.A.; Reynolds, K.A. Modeling COVID-19 infection risks for a single hand-tofomite scenario and potential risk reductions offered by surface disinfection. Am. J. Infect. Control 2020. [CrossRef]

70. Wolfel, R.; Corman, V.M.; Guggemos, W.; Seilmaier, M.; Zange, S.; Muller, M.A.; Niemeyer, D.; Jones, T.C.; Vollmar, P.; Rothe, C.; et al. Virological assessment of hospitalized patients with COVID-2019. Nature 2020, 581, 465-469. [CrossRef]

71. To, K.K.; Tsang, O.T.; Leung, W.S.; Tam, A.R.; Wu, T.C.; Lung, D.C.; Yip, C.C.; Cai, J.P.; Chan, J.M.; Chik, T.S.; et al. Temporal profiles of viral load in posterior oropharyngeal saliva samples and serum antibody responses during infection by SARS-CoV-2: An observational cohort study. Lancet Infect. Dis. 2020, 20, 565-574. [CrossRef]

72. Weber, D.J.; Anderson, D.; Rutala, W.A. The role of the surface environment in healthcare-associated infections. Curr. Opin. Infect. Dis. 2013, 26, 338-344. [CrossRef]

73. WHO. Cleaning and Disinfection of Environmental Surfaces in the Context of COVID-19. Interim Guidance. 19 May 2020. Available online: https:/ / www.who.int/publications/i/item/cleaning-and-disinfection-of-environmental-surfaces-inthe-contextof-COVID-19 (accessed on 18 August 2020).

74. CDC. Cleaning and Disinfection for Community Facilities. Interim Recommendations for U.S. Community Facilities with Suspected/Confirmed Coronavirus Disease 2019 (COVID-19). 27 May 2020. Available online: https:/ /www.cdc.gov/coronavirus / 2019-ncov/community/organizations/cleaning-disinfection.html (accessed on 18 August 2020).

75. Robert Koch-Institut. Hinweise zu Reinigung und Desinfektion von Oberflächen Außerhalb von Gesundheitseinrichtungen im Zusammenhang Mit der COVID-19-Pandemie. Available online: https:/ /www.rki.de/DE/Content/InfAZ/N/Neuartiges_ Coronavirus/Reinigung_Desinfektion.html (accessed on 4 April 2020).

76. Dick, E.C.; Jennings, L.C.; Mink, K.A.; Wartgow, C.D.; Inhorn, S.L. Aerosol transmission of rhinovirus colds. J. Infect. Dis. 1987, 156, 442-448. [CrossRef]

77. Ansari, S.A.; Springthorpe, V.S.; Sattar, S.A.; Rivard, S.; Rahman, M. Potential role of hands in the spread of respiratory viral infections: Studies with human parainfluenza virus 3 and rhinovirus 14. J. Clin. Microbiol. 1991, 29, 2115-2119. [CrossRef]

78. Wilson, A.M.; Reynolds, K.A.; Sexton, J.D.; Canales, R.A. Modeling surface disinfection needs to meet microbial risk reduction targets. Appl. Environ. Microbiol. 2018, 84, e00709-e00718. [CrossRef] [PubMed] 
79. Moriyama, M.; Hugentobler, W.J.; Iwasaki, A. Seasonality of respiratory viral infections. Ann. Rev. Virol. $2020,7,83-101$. [CrossRef] [PubMed]

80. Biryukov, J.; Boydston, J.A.; Dunning, R.A.; Yeager, J.J.; Wood, S.; Reese, A.L.; Ferris, A.; Miller, D.; Weaver, W.; Zeitouni, N.E.; et al. Increasing temperature and relative humidity accelerates inactivation of SARS-CoV-2 on surfaces. mSphere 2020, 5. [CrossRef] [PubMed]

81. Morris, D.H.; Yinda, K.C.; Gamble, A.; Rossine, F.W.; Huang, Q.; Bushmaker, T.; Fischer, R.J.; Matson, M.J.; Van Doremalen, N.; Vikesland, P.J.; et al. Mechanistic theory predicts the effects of temperature and humidity on inactivation of SARS-CoV-2 and other enveloped viruses. eLife 2021, 10, e65902. [CrossRef]

82. Jefferson, T.; Del Mar, C.; Dooley, L.; Ferroni, E.; Al-Ansary, L.A.; Bawazeer, G.A.; van Driel, M.L.; Foxlee, R.; Rivetti, A. Physical interventions to interrupt or reduce the spread of respiratory viruses: Systematic review. BMJ Clin. Res. 2009, 339, b3675. [CrossRef]

83. Malenovská, H. Coronavirus persistence on a plastic carrier under refrigeration conditions and its reduction using wet wiping technique, with respect to food safety. Food Environ. Virol. 2020, 12, 1-6. [CrossRef]

84. Cutts, T.A.; Robertson, C.; Theriault, S.S.; Nims, R.W.; Kasloff, S.B.; Rubino, J.R.; Ijaz, M.K. Assessing the contributions of inactivation, removal, and transfer of ebola virus and vesicular stomatitis virus by disinfectant pre-soaked wipes. Front. Public Health 2020, 8, 183. [CrossRef] [PubMed]

85. Mahnert, A.; Moissl-Eichinger, C.; Zojer, M.; Bogumil, D.; Mizrahi, I.; Rattei, T.; Martinez, J.L.; Berg, G. Man-made microbial resistances in built environments. Nat. Commun. 2019, 10, 968. [CrossRef]

86. Tun, M.H.; Tun, H.M.; Mahoney, J.J.; Konya, T.B.; Guttman, D.S.; Becker, A.B.; Mandhane, P.J.; Turvey, S.E.; Subbarao, P.; Sears, M.R.; et al. Postnatal exposure to household disinfectants, infant gut microbiota and subsequent risk of overweight in children. Can. Med. Assoc. J. 2018, 190, e1097-e1107. [CrossRef] [PubMed]

87. Cassini, A.; Hogberg, L.D.; Plachouras, D.; Quattrocchi, A.; Hoxha, A.; Simonsen, G.S.; Colomb-Cotinat, M.; Kretzschmar, M.E.; Devleesschauwer, B.; Cecchini, M.; et al. Attributable deaths and disability-adjusted life-years caused by infections with antibiotic-resistant bacteria in the eu and the european economic area in 2015: A population-level modelling analysis. Lancet Infect. Dis. 2018, 19, 56-66. [CrossRef]

88. Kampf, G. Antiseptic Stewardship: Biocide Resistance and Clinical Implications; Springer International Publishing: Cham, Switzerland, 2018.

89. Chang, A.; Schnall, A.H.; Law, R.; Bronstein, A.C.; Marraffa, J.M.; Spiller, H.A.; Hays, H.L.; Funk, A.R.; Mercurio-Zappala, M.; Calello, D.P.; et al. Cleaning and Disinfectant Chemical Exposures and Temporal Associations with COVID-19-National Poison Data System, United States, 1 January 2020-31 March 2020. MMWR Morb. Mortal. Wkly. Rep. 2020, 69, 496-498. [CrossRef] [PubMed]

90. McNamara, P.J.; Levy, S.B. Triclosan: An instructive tale. Antimicrob. Agents Chemother. 2016, 60, 7015-7016. [CrossRef] [PubMed]

91. Liu, Y.; Li, T.; Deng, Y.; Liu, S.; Zhang, D.; Li, H.; Wang, X.; Jia, L.; Han, J.; Bei, Z.; et al. Stability of SARS-CoV-2 on environmental surfaces and in human excreta. J. Hosp. Infect. 2020, 107, 105-107. [CrossRef] 